\title{
MEASURING AND MAKING THE WORLD: SELF-PROMOTION, COSMOLOGY AND ELITE APPEAL IN FILARETE'S LIBRO ARCHITETTONICO
}

\author{
Helena GuZik \\ UNIVERSITY OF OXFORD \\ United KINGDOM
}

Date of receipt: $21^{\text {st }}$ of February, 2020

Date of acceptance: $23^{\text {rd }}$ of July, 2020

\section{Abstract}

Antonio Averlino (Filarete) (c. 1400-c. 1469) is best remembered for his architectural treatise, the Libro architettonico. Despite a longstanding tradition, beginning with Vasari, of dismissing Filarete as a mediocre artist with ridiculous ideas, his treatise ended up in some of the most prestigious courts within and beyond Italy. This article, in a corrective to that narrative, argues that Filarete was an incredibly ambitious artist and that the Libro was his attempt to channel intellectual trends of interest to the fifteenth-century ruling elite whose patronage he courted. It begins by situating the Libro within the broader context of Filarete's consistent self-promotion and shrewd networking throughout his career. It then examines, through analysis of the text and illustrations, how the Libro was designed both to promote Filarete to his patrons and appeal to contemporary patronage tastes through its use of specific themes: ideal urban design, cosmology, and universal sovereignty.

\section{KeYwords}

Architectural Treatise, Cosmology, Intellectual Networks, Italian Court Culture, Fifteenth-century Art.

\section{Capitalia verba}

Tractatus architecturae, Cosmologia, Reta sapientium, Cultura iudiciaria Italica, Ars saeculi quindecimi. 
Like many of his humanist contemporaries, Antonio Averlino (c. 1400-c. 1469) had a predilection for wordplay. Adopting the nickname "Filarete" later in life, he cultivated his identity as a "lover of virtue", the name's Greek meaning. ${ }^{2}$ However the name can also be read in Italian as fila/rete ("he spins a net"). ${ }^{3}$ This linguistic coincidence is more than fitting since Filarete did precisely that, actively promoting himself and cultivating his patronage network throughout his career, in spite of personal and circumstantial obstacles. Despite a tendency, beginning with Giorgio Vasari (1511-1574) and extending into modern scholarship, of dismissing Filarete for his lack of formal education, lack of a school of followers and fanciful architectural designs, he was more savvy an artist and more skilled a networker than he has generally been given credit for being. ${ }^{4}$ This study sheds light on Filarete's business acumen and his appeal to patrons' tastes in Italy and beyond through a reassessment of his architectural treatise, the Libro architettonico. Filarete's Libro is a deliberate attempt, through flattering appeals to patrons and a demonstrated familiarity with scholarly authorities, to assert his relevance to a courtly audience. The complex themes embedded in the treatise -ideal urban design, cosmology and universal sovereignty- were included specifically to appeal fifteenth-century courtly patrons and their collecting habits.

Born in Florence c. 1400, Filarete began his career as a bronze sculptor. In 1433 he went to Rome, where he worked on the new doors of St. Peter's Basilica until 1445. Political tumult following the death of Pope Eugenius IV (1383-1447) disrupted Filarete's professional network in Rome and he fled the city. After a series of travels Filarete entered the service of Duke Francesco Sforza (1401-1466) in Milan in 1451, where he worked on the Duomo, the Castello and the Ospedale Maggiore, among other projects. Extended financial disputes eventually prompted Filarete's departure from Sforza's service, despite still being owed a substantial amount of his salary. Filarete probably left Milan in 1465, but there our trail of documents directly

1. This research was financially supported by Kettle's Yard and St. John's College (University of Cambridge). I would also like to express my gratitude to Deborah J. Howard for her expertise and guidance on this project in its original form, as well as to Donal Cooper, Geraldine A. Johnson, Adam F. C. Brodie, and the anonymous reviewers who provided invaluable feedback on earlier versions of this article.

2. Prior to the late 1450s, Averlino only hinted at ideas that would serve as his nickname's inspiration. For clarity, I will refer to him as Filarete throughout this article.

3. Whittemore, Leila. "City and Territory in Filarete's Libro architettonico". Arte Lombarda, 155 (2009): 47. 4. Vasari, Giorgio. Le vite de' più eccellenti pittori, scultori, e architettori nelle redazioni del 1550 e 1568, eds. Rosanna Bettarini, Paola Barocchi. Florence: Sansoni Editore, 1966-1987: III, 243-46. Despite Filarete's interesting place in the history of architectural treatises, he frequently gets short shrift because of the impulse to compare him to his forerunner in that tradition, Leon Battista Alberti (1404-1472), see esp. Onians, John. "Alberti and ФІ ААРЕТН. A Study in Their Sources". Journal of the Warburg and Courtauld Institutes, 34 (1971): 104; Hollingsworth, Mary. "The Architect in Fifteenth-Century Florence". Art History, 7/4 (1984): 396; Long, Pamela O. "The Contribution of Architectural Writers to a 'Scientific' Outlook in the Fifteenth and Sixteenth Centuries". Journal of Medieval and Renaissance Studies, 15 (1985): 273; Onians, John. Bearers of Meaning: The Classical Orders in Antiquity, the Middle Ages, and the Renaissance. Cambridge: Cambridge University Press, 1988: 158-160; Woods-Marsden, Joanna. Renaissance SelfPortraiture: The Visual Construction of Identity and the Social Status of the Artist. New Haven: Yale University Press, 1998: 79, 82-83. 
attesting to his whereabouts ends. A letter, dated 30 July 1465, from his humanist friend and mentor, Francesco Filelfo (1398-1481), to Ottoman court scholar George Amirutzes (1400-1470) explains that Filarete was planning a trip to Constantinople, but whether he ever made the journey is unknown. ${ }^{5}$ Filarete died c. 1469 and his final days were probably spent in Florence or Rome. ${ }^{6}$

Alongside his architectural work in Milan, Filarete also wrote his Libro, dedicated to Francesco Sforza, in the early 1460s. ${ }^{7}$ In 1464 he amended and rededicated the Libro to Piero de' Medici (1416-1469). ${ }^{8}$ Other patrons obtained copies of the treatise after Filarete's lifetime. The Neapolitan royal collection possessed one by 1482, and another copy was made later for Cardinal Giovanni d'Aragona (1456-1485), son of King Ferrante of Naples. ${ }^{9}$ In 1487 Hungarian King Matthias Corvinus (1443-1490) commissioned a Latin translation of the Medici manuscript. ${ }^{10}$ The scholarship to date lacks a systematic examination of the reasons for these patrons' interest in Filarete. How did he come to their attention and what earned his treatise a place in some of the most prestigious libraries of the fifteenth century?

5. Letter reproduced in Restle, Marcell. "Bauplanung und Baugesinnung unter Mehmet II. Fâtih: Filarete in Konstantinopel". Pantheon, 39 (1981): 366, No. 29. On the degree to which Filarete and/or his designs and theories made their way to the Ottoman Empire, see Raby, Julian. El Gran Turco: Mehmed the Conqueror as Patron of the Arts of Christendom. Oxford: University of Oxford (PhD Dissertation), 1980: 17-29; Necipoğlu, Gülru. Architecture, Ceremonial, and Power: The Topkapı Palace in the Fifteenth and Sixteenth Centuries. Cambridge (Mass.): The Massachusetts Institute of Technology Press, 1991: 267; Restle, Marcell. "Bauplanung und Baugesinnung...": 361-367; Quadflieg, Ralph. Filaretes Ospedale Maggiore in Mailand: Zur Rezeption islamischen Hospitalwesens in der italienischen Frührenaissance. Cologne: Abteilung Architektur des Kunsthistorischen Instituts, 1981.

6. On Filarete's life, see [Averlino, Antonio detto il] Filarete. Trattato di Architettura, eds. Anna Maria Finoli, Liliana Grassi. Milan: Edizioni il Polifilo, 1972: I, lxxxviii-xci; Spencer, John R. "Introduction", Filarete's Treatise on Architecture, Being the Treatise by Antonio Averlino, Known as Filarete, Antonio Averlino (Filarete), ed. John R. Spencer. New Haven-London: Yale University Press, 1965: xviii-xix; Giordano, Luisa. "On Filarete's Libro Architettonico", Paper Palaces: The Rise of the Renaissance Architectural Treatise, Vaughan Hart, Peter Hicks, eds. New Haven: Yale University Press, 1998: 51; Lang, Susanne. "Sforzinda, Filarete and Filelfo". Journal of the Warburg and Courtauld Institutes, 35 (1972): 391; Romanini, Angiola Maria. "Averlino (Averulino), Antonio, detto Filarete", Dizionario Biografico degli Italiani. Rome: Istituto della Enciclopedia Italiana, 1962: IV, 662-665.

7. Filarete's original manuscript is not extant. The version produced for Francesco Sforza survives only in fragments. Filarete. Trattato di Architettura... I, cix-cx.

8. Commonly known as the Codex Magliabechianus, now housed in the Biblioteca Nazionale Centrale di Firenze. Ms. Magl.II.I.140. With the exception of the altered preface and amended final book, this version is considered to be a close copy of the Sforza version and was produced in Milan, likely under Filarete's direct supervision, and forms the basis for most modern Filarete scholarship. On the different manuscripts see Spencer, John R. "Introduction...": xvii-xviii; Vulpi, Valentina. “Finding Filarete: The Two Versions of the Libro Architettonico", Raising the Eyebrow: John Onians and World Art Studies: An Album Amicorum in His Honour, ed. Lauren Golden. Oxford: Archaeopress, 2001: 329-339.

9. Clarke, Georgia. "Vitruvian Paradigms". Papers of the British School at Rome, 70 (2002): 327.

10. This copy (the Codex Corvina) is now housed in the Biblioteca Nazionale Marciana. MS Lat.VIII.2. Full transcription available in Beltramini, Maria. La latinizzazione del Trattato d'Architettura di Filarete (14881489). Pisa: Scuola Normale Superiore, 2000. See also Marcon, Susy. "Treatise on architecture by Filarete for the library of Matthias Corvinus", Matthias Corvinus, the King: Tradition and Renewal in the Hungarian Royal Court, 1458-1490, Péter Farbaky, Ágnes Bakos, Beatrix Basics, Budapesti Történeti Múzeum, eds. Budapest: Budapest History Museum, 2008: 331. 


\section{Filarete's ambition}

Whatever loftier ideas of his profession he may have entertained, Filarete was always aware that he was in the business of making art. Marketing himself to patrons and paying careful attention to the individual interests of his potential clientele allowed Filarete to overcome professional challenges and remain relevant to the study of Quattrocento architecture over 500 years later. To fully understand Filarete's intentions it is essential to remember that he worked in the wake of Alberti's assertion that the fine arts, and particularly architecture, ought not to be considered akin to manual crafts, but rather should be accorded the elevated status of a liberal art - a knowledge-producing pursuit of the mind suitable for noble gentlemen. ${ }^{11}$ The social status of artists became a topic of much discussion and debate for centuries thereafter, but Filarete's works are among some of the earliest and most emphatic examples of an artist making this self-assertion.

\subsection{The doors of St. Peter's}

These ambitions first manifested themselves in Filarete's work on the new doors of St. Peter's. ${ }^{12}$ (Illustration 1) Traditional Christian iconography -panels depicting Christ and the Virgin enthroned, as well as Saints Peter and Paul and scenes of their martyrdoms - is interspersed with panels celebrating Eugenius IV's achievements. ${ }^{13}$ Acanthus vines scroll up the sides of the doors, bearing portraits of Roman emperors interspersed with historical and mythological scenes. ${ }^{14}$ Robert Glass has devoted considerable attention to Filarete's assertions of authorship and status in the doors' program, particularly to a small relief tucked at the base of the back of the doors, depicting Filarete processing with a troupe of assistants. ${ }^{15}$ (Illustration 2) However, this is not Filarete's only self-reference in the work: there are two further self-portraits and three signatures on the front of the doors. ${ }^{16}$ One self-portrait can be found, set into an acanthus scroll that likely originally contained a portrait of a Roman emperor, just to the left and facing the panel celebrating

\footnotetext{
11. Alberti, Leon Battista. On the Art of Building in Ten Books, trans. Joseph Rykwert, Neil Leach, Robert Tavernor. Cambridge (Mass.): Masachussetts Institute of Technology Press, 1988: 3; Hart, Vaughan. "Paper Palaces' from Alberti to Scamozzi", Paper Palaces: The Rise of the Renaissance Architectural Treatise, Vaughan Hart, Peter Hicks, eds. New Haven: Yale University Press, 1998: 14.

12. Glass, Robert. "Filarete's Renovation of the Porta Argentea", Old St. Peter's, Rome, Rosamond McKitterick, John Osborne, Carol M. Richardson, Joanna Stiry, eds. Cambridge: Cambridge University Press, 2013: 348.

13. Glass, Robert. "Filarete's Hilaritas: Claiming Authorship and Status on the Doors of St. Peter's". The Art Bulletin, 94/4 (2012): 559-560. For images and detailed iconographic explanations, see Glass, Robert. "Filarete's Renovation...": 367; Roeder, Helen. "The Borders of Filarete's Bronze Doors to St. Peter's". Journal of the Warburg and Courtauld Institutes, 10 (1947): 150-153.

14. Roeder, Helen. "The Borders...": 150-153.

15. Glass, Robert. "Filarete's Hilaritas...": 548-571.

16. Glass, Robert. "Filarete's Hilaritas...": 548.
} 
Eugenius's reception of the Greeks. ${ }^{17}$ (Illustration 3) Another appears at the base of the relief of St. Paul's martyrdom, on a medallion set into the pedestal, while around the portrait an inscription reads ANT(O)NIVS PETRI DE FLORENTIA FECIT $M C C C C X L V .^{18}$ (Illustration 4) The base of the St. Peter's martyrdom relief includes a similar medallion bearing the artist's signature: OPVS ANTONII. ${ }^{19}$ (Illustration 5) Finally, directly under the scenes of the coronation of Sigismund, Filarete included a simple signature inscription that reads OPVS ANTONII DE FLORENTIA. ${ }^{20}$

Signing a work of this nature and significance echoes Lorenzo Ghiberti (13781455)'s inclusion of a signature and self-portrait on the doors of the Florentine baptistery, and if we accept the prevailing theory that Filarete initially trained in Ghiberti's workshop, the parallel was undoubtedly intentional. However, Filarete tripled the number of self-references that Ghiberti saw fit to include. Even more remarkable than the quantity is the nature of those authorship claims. Not only does he allow himself a self-portrait roundel in the style of the Roman emperors, but Glass has convincingly detailed how Filarete made visual parallels between himself and his papal patron..$^{21}$ By emphatically asserting his authorship on so prominent a commission, and doing so in a way that made evident parallels between himself and the nobility, Filarete made a bold statement about his own status. His claim to a place in the courtly culture - made through demonstrations of knowledge about antiquity and awareness of the types of ornate details preferred by wealthy patrons, in addition to self-aggrandizing references- was an attempt to elevate himself above the role of a humble artisan, and so increase his appeal to future patrons.

\subsection{Portrait medals}

These aspirations played out on a smaller scale as well. Toward the end of his time in Milan (around 1464-1465), Filarete produced a self-portrait medal, the obverse of which depicts the artist in profile, his head encircled with the inscription ANTONIVS AVERLINVS ARCHITECTVS and surrounded by three bees.22 (Illustration 6) The Latin inscription on the reverse of the medal reads VT SOL AVGET APES SIC NOBIS COMODA PRINCEPS. ${ }^{23}$ The medal could have been made to court the patronage of either Galeazzo Maria Sforza (1444-1476), next in succession at the Milanese court, or Piero de' Medici, as financial arrangements for Filarete's work on the Ospedale Maggiore in Milan were deteriorating and his need for a new patron

17. Glass, Robert. "Filarete's Hilaritas...": 560-561.

18. "Antonio di Piero from Florence made [this], 1445". Glass, Robert. "Filarete's Hilaritas...": 561.

19. "the work of Antonio". Glass, Robert. "Filarete's Hilaritas...": 561.

20. "the work of Antonio of Florence". Glass, Robert. "Filarete's Hilaritas...": 561.

21. Glass, Robert. "Filarete's Hilaritas...": 560-61.

22. "Antonio Averlino the architect".

23. "As the sun causes the bees to flourish, so the [patronage of] princes has the same beneficial [effects]". Woods-Marsden, Joanna. Renaissance Self-Portraiture...: 81. 
became acute. ${ }^{24}$ Portrait medals were favoured in fifteenth-century Italian courts for their long-standing association with coin and cameo portraits of classical Roman emperors, and because they were a convenient way of projecting the patron's fame and nobility to a select audience of recipients. ${ }^{25}$ Filarete was not the first artist to depict himself in this fashion -Alberti made a bronze self-portrait plaquette in the 1430s, and Pisanello (c. 1395-1455) had his own portrait medal created in the $1440 \mathrm{~s} .{ }^{26}$ In all three cases, the artists used forms of representation previously been reserved for nobles for their own medals. By representing himself in a manner and medium associated with virtue, antiquity and nobility, Filarete asserted his status to a courtly audience. ${ }^{27}$

Filarete produced only one portrait medal of a contemporary - that of his humanist mentor, Francesco Filelfo. ${ }^{28}$ The two medals were possibly pendant pieces and, when considered together, demonstrate another attempt by Filarete to portray himself in the same social strata as the elites in society -in this case as a respected court intellectual and humanist rather than as a ruler. ${ }^{29}$ Filelfo, not born to an aristocratic background, embodied the ideal of rising above one's allotted station in life through industry, courting patrons and the successful application of one's scholarly skills. If Filarete's goal was soliciting patronage and promoting his personal worth to a court, visually associating himself with Filelfo and implying their similar qualities was a plausible strategy to adopt.

Whereas the doors of St. Peter's were a monumental way of leaving his mark, Filarete's portrait medals were more personal and intimate. The medals could be easily distributed to selected individuals in what would appear to be a benevolent and magnanimous gesture. ${ }^{30}$ Such gifts were implicitly self-promoting: they acted both as demonstrations of artistic skill and, in the case of the self-portrait, tacit assertions of the artist's nobility. But it is another type of work, created for a much

\footnotetext{
24. Raby, Julian. El Gran Turco...: 24; Spencer, John. "Filarete, the Medallist of the Roman Emperors". The Art Bulletin, 61/4 (1979): 552.

25. See Hill, George F. Portrait Medals of Italian Artists of the Renaissance. London: Philip Lee Warner, 1912: 1-25; Scher, Stephen K., ed. The Currency of Fame: Portrait Medals of the Renaissance. London: Thames 8 Hudson Ltd., 1994: 13-21; Syson, Luke. "Holes and Loops: The Display and Collection of Medals in Renaissance Italy". Journal of Design History, 15/4 (2002): 229-244.

26. Scher, Stephen K., ed. The Currency of Fame...: 41-59.

27. Glass, Robert. "Filarete's Hilaritas...": 566.

28. Raby, Julian. El Gran Turco ...: 24.

29. Raby, Julian. El Gran Turco...: 24.

30. On the development of gift-giving, see Davis, Natalie Zemon. The Gift in Sixteenth-Century France. Oxford: Oxford University Press, 2000: 56-72, 142-166; Howard, Deborah. "Cultural transfer between Venice and the Ottomans in the fifteenth and sixteenth centuries", Cultural Exchange in Early Modern Europe, vol. IV: Forging European Identities, 1400-1700, Herman Roodenburg, ed. Cambridge: Cambridge University Press, 2007: 142-143; Clark, Leah R. “Collecting, Exchange, and Sociability in the Renaissance Studiolo". Journal of the History of Collections, 25/2 (2013): 171-184. On gifting portrait medals, see Hill, George F. Portrait Medals...: 8-9; Leino, Marika. Fashion, Devotion and Contemplation: The Status and Functions of Italian Renaissance Plaquettes. Bern: Peter Lang, 2012: 249-250; Clark, Leah R. “Collecting, Exchange and Sociability...": 3-6.
} 
more limited viewership, which will be the main focus of the rest of this study: his architectural treatise, the Libro architettonico.

\subsection{The Libro architettonico}

Filarete's Libro is replete with examples of its author's self-promotion and ambition. Throughout, Filarete appears not so subtly as its protagonist, the architect Onitoan Noliaver, an anagram of his name. There is never any doubt about authorship -the frontispiece identifies [i]l tuo filareto architetto Antonio Averlino fiorentino. ${ }^{31}$ Nevertheless Filarete has managed to repeatedly "sign" the treatise, just as he embedded his signatures on the doors of St. Peter's. The Codex Magliabechianus begins with an illuminated initial depicting a patron consulting with a mason and an architect; the latter is considered to be a self-portrait of Filarete. ${ }^{32}$ (Illustration 7) In addition to naming the hypothetical city, Sforzinda, after his patron, he also names the drawing of the city Averliano - derived from his own name. ${ }^{33}$ Near the city, Filarete notes the river and lake Averlo as potentially abundant resources for Sforzinda; by implicit analogy, the reader is to understand that Filarete is therefore a great resource for his patron. ${ }^{34}$ One of Sforzinda's gates which leads to the Averlo river is also named Averlina. Since the rest of the city gates are named after members of the Sforza household, his own inclusion grants Filarete a privileged place in his patron's inner circle -in this case manifested in the literal circle of Sforzinda's outer wall. ${ }^{35}$ A similar ploy to glorify and elevate the artist emerges in the dialogue pertaining to the construction of the bridge leading to Sforzinda's port city, Plusiapolis: the patron insists that the architect inscribe the bridge with its patronage details, but also identifies who made it and how, and includes Noliaver/ Filarete's relief self-portrait. ${ }^{36}$

In addition to the numerous embedded self-allusions, Filarete's Libro also pursues an overall reassessment of the social standing of architects in general. He deliberately distances himself from common artisans and artists, while promoting the status of the intellectual architect. The most blatant distinction can be found in comparing the descriptions of the houses assigned to the artists and artisans with that of the protagonist architect's residence. ${ }^{37}$ In a section describing the houses of gentlemen, merchants and artisans, the latter are identified as the lowest class. ${ }^{38}$ As such, they

\footnotetext{
31. "your Filareto architect, Antonio Averlino, the Florentine". Filarete. Treatise on Architecture...: 3. Averlino, Antonio (Filarete). Trattato di Architettura...: I, 5.

32. Filarete. Trattato di Architettura...: I, xvii.

33. Filarete. Trattato di Architettura...: I, 53.

34. Filarete. Trattato di Architettura...: I, 146.

35. Filarete. Trattato di Architettura...: I, 146. On the Sforza name resemblance see Filarete. Treatise on Architecture...: 65, No. 8.

36. Filarete. Trattato di Architettura...: I, 414-415.

37. Woods-Marsden, Joanna. Renaissance Self-Portraiture...: 83-84.

38. Averlino, Antonio (Filarete). Trattato di Architettura ...: I, 323-330.
} 
are accorded a house of the Ionic order, with the smallest floorplan of the three, and outfitted with basic amenities. Justifying this, Filarete explains: "Delle altre comodità che bisognano nella casa, come che nelle altre sono fatti e ordinati, così nel grado suo arà questa. Non accade di mostrare: quando sarà fatta, secondo da artigiano e persona mediocre sarà bella assai". ${ }^{39}$

When Filarete later addresses the house of his fictional counterpart architect, he designs a taller building whose floorplan is over double the size of that of the artisans'. The house also has an enviable location near the House of Virtue and is decorated with elaborate frescoes of noble subjects, to which he dedicates a description spanning fifteen pages of the treatise. ${ }^{40}$ Within this decorative program that begins with representations of all the masters of each of the arts, the architects conspicuously come first. ${ }^{41}$ This is not surprising, since early in the treatise Filarete boldly counsels:

dee essere onorato e amato da chi fa fare non altrimenti che lui disidera che 'l suo dificio vadia bene, né con altro amore e diligenza che s'ha inverso di quella sanza la quale generare uomo non si può, neanche sanza l'architetto non si può generare, né dedicare edificio che stia bene, per le ragioni antedette. E perché ancora sono in rari queste scienze, e per questo ne dee essere fatto stima, però che l'uomo è detto gentile tanto quanto egli ha virtù. ${ }^{42}$

This elevation of architecture is inherently woven into the structure of the Libro as well. The treatise, with its narrative tone, moralizing philosophies linking architecture with good governance (a theme to be explored later), and the presentation of its author as a valued advisor to the ruling patron, echoes the tradition of mirrors for princes. ${ }^{43}$ Such narratives were common among the humanists with whom Filarete would have interacted in both the papal and Milanese courts: his close associate Filelfo in fact produced several of these intellectual and moralizing narratives for rulers. ${ }^{44}$ The work of fifteenth-century artists and intellectuals necessitated constant

39. "The other houses had their conveniences; so this one will have its [conveniences] in its own degree. [...] When it is built, it will be beautiful enough for an artisan or other modest person". Filarete. Treatise on Architecture...: 150. Averlino, Antonio (Filarete). Trattato di Architettura...: I, 331.

40. Averlino, Antonio (Filarete). Trattato di Architettura...: II, 557-586. Individualised housing for court artists existed in reality: Warnke, Martin. The court artist. On the ancestry of the modern artist. Cambridge: Cambridge University Press, 1993: 126-127.

41. Averlino, Antonio (Filarete). Trattato di Architettura...: II, 563.

42. "the patron should love and honor [the architect] insofar as he wants his building to go well and should show him the same love and devotion as he does to his wife. Without the architect one cannot conceive or dedicate a good building for the above reasons. His knowledge is rare and he should be esteemed for it, because a man is called [noble] insofar as he has virtù". Filarete. Treatise on Architecture...: 18. Averlino, Antonio (Filarete). Trattato di Architettura...: I, 44-45.

43. Tönnesmann, Andreas. "Il dialogo di Filarete: l'architetto, il principe e il potere". Arte Lombarda, 155 (2009): 8; Lang, Susanne. "Sforzinda, Filarete and Filelfo...": 394-396.

44. One example is Filelfo's De morali disciplina, written for Lorenzo de' Medici (1449-1492) between 1473 and 1475. Biblioteca Medicea Laurenziana. Ms.Plut.76.69. See Robin, Diana. Filelfo in Milan: Writings 1451-1477. Princeton: Princeton University Press, 1991: 42-43, 138-166. On counsel between princes and courtiers, see Bueno de Mesquita, Daniel Meredith. "The Conscience of the Prince", Art and 
contact with courtly culture, and professional success demanded intuition about the tastes of the reigning patrons and deft manoeuvring within a long-established system of rhetoric and symbolism.

Nevertheless, the treatise asserts Filarete's primacy in decisions regarding the design and governance of Sforzinda in a bold way that one might expect from a trusted courtier, but not, perhaps, from an artist struggling to establish his reputation in the court. When the patron expresses confusion or suggests a course of action with which Filarete disagrees, the architect is quick to offer alternative suggestions and explain his careful reasoning. These explanations frequently adopt a philosophical tone, with Filarete referencing antiquity, divine providence and the logical dictates of nature when justifying his decisions. His patron almost always defers to Filarete's experience and wisdom -an outcome that was probably not the reality for most Quattrocento artists. ${ }^{45}$ That his fictional patronage relationship is so cooperative and agreeable confirms Filarete's esteem, real or imagined, in the eyes of the court.

While social hierarchies in the Libro never fully break down and Filarete qua narrator maintains a respectful and deferential tone toward his patron, the familiarity and authority he adopts is noteworthy. Already subtly suggested in the dialogue structure and the give-and-take of ideas that characterises discussions about the city's creation, the Libro emphasises that the architect-patron relationship is one of symbiosis. Filarete likens the patron to the father, and the architect to the mother, of a building, saying:

che sì come niuno per sé solo non può generare sanza la donna un altro, così eziandio a similitudine lo edificio per uno solo non può essere creato [...] così colui che vuole edificare bisogna che abbia l'architetto e insieme collui ingenerarlo, e poi l'architetto partorirlo ${ }^{46}$

An interesting invocation of the Renaissance male-female hierarchy, this proposed paradigm allows Filarete to assert his indispensable role in the architectural creation process without threatening the hierarchical relationship of patron to artist. ${ }^{47}$

In its very structure and tone the Libro makes a powerful argument for the importance and prestige of the artist. Rather than portraying himself as a skilled and deferential craftsman carrying out his patron's vision, Filarete proposes a unique and far-sighted project that will benefit the ruler and his subjects, and which will serve as a model city for the world. In so doing he adopts the role of the philosopher/

Politics in Renaissance Italy: British Academy Lectures, George Holmes, ed. Oxford: Oxford University Press, 1993: 160-161.

45. On Filarete's own professional difficulties in Milan, see Woods-Marsden, Joanna. Renaissance SelfPortraiture...: 84 .

46. "Since no one can conceive by himself without a woman, by another simile, the building cannot be conceived by one man alone. [...] he who wishes to build needs an architect. He conceives it with him and then the architect carries it". Translation by Spencer: Filarete. Treatise on Architecture...: 15; Averlino, Antonio (Filarete). Trattato di Architettura ...: I, 40. On artist and patron as joint creators of the city, see Giordano, Luisa. "On Filarete's Libro Architettonico...": 56; Hollingsworth, Mary. "The Architect...": 398406.

47. Tönnesmann, Andreas. "Il dialogo di Filarete...": 9. 
intellectual who can convey harmony, wisdom and universal truths visually. Aware of potential challenges to this narrative, however, Filarete is careful to couch his claims about the noble and intellectual artist in references to antiquity's precedent - particularly through the example of Vitruvius as well as the relationship between Dinocrates (d. 278 BC) and Alexander the Great (356-323 BC). He also delineates all the requisite areas of knowledge with which architects must be familiar, to provide a foundation for his assertion of their intellectual authority. When confronted with an artist trained in disegno, geometry, astrology, arithmetic, philosophy, music, rhetoric, medicine, history and law, it would be difficult to dispute his professional opinions. ${ }^{48}$

This line of argument follows Alberti's precedent, but Filarete conveys his agenda not in a highly structured, intellectual treatise, but rather in a narrative format closer to medieval literary traditions and more immediately accessible to his target audience. Alberti explains the theoretical role of the artist and his relationship with patrons, but requires readers to imagine these proposed dynamics for themselves. In Filarete's Libro, however, the character of the noble artist and the symbiotic artistpatron relationship are already fully realised and demonstrated through a series of conversations, meaning the reader could accept these ideas as plausible without too much imagination, perhaps easing the path to their eventual acceptance.

\subsection{Filarete's intellectual network}

Given his aspirations, it is no surprise that Filarete cultivated personal relationships with some of the most influential intellectuals of his day. The most important and best documented of these was his friendship with Francesco Filelfo. ${ }^{49}$ This association was invaluable for augmenting Filarete's professional contacts and giving him access to a network of intellectuals. Filarete also would have encountered other scholars through his work in the courts of Rome, Florence and Milan. For example, Filarete may have met the antiquarian and travel chronicler Ciriaco d'Ancona (13911452) shortly after his arrival in Rome in 1433, when Ciriaco advised the pope on Sigismund's coronation. ${ }^{50}$ The sophisticated detail of the ancient scenes on Filarete's bronze doors suggests the expert advisory assistance of an antiquarian, and in Rome's early 1430s there was none more qualified than Ciriaco. ${ }^{51}$

\footnotetext{
48. Filarete. Trattato di Architettura...: II, 427-432. Filarete echoes Book I of Vitruvius's De architectura: Vitruvius. Ten Books on Architecture, ed. Thomas Noble Howe. Cambridge: Cambridge University Press, 1999: 22-23. On Renaissance attitudes toward Vitruvius, see Clarke, Georgia. "Vitruvian Paradigms...": 327.

49. Lang, Susanne. "Sforzinda, Filarete and Filelfo...": 391-397; Onians, John. Bearers of Meaning...: 160162; Johnston, Marina della Putta. "The Literary Cornice of Architecture in Filarete's Libro architettonico". Arte Lombarda, 155 (2009): 16; Robin, Diana. Filelfo in Milan...: 3-10.

50. Scalamonti, Francesco. Vita Viri Clarissimi et Famosissimi Kyriaci Anconitani, eds. Charles Mitchell, Edward W. Bodnar. Philadelphia: American Philosophical Society, 1996: 1.

51. Glass, Robert. "Filarete's Renovation...": 368-369; Raby, Julian. El Gran Turco...: 19.
} 
Fostering personal and professional relationships with scholars presented valuable inroads to the courts, and to the most wealthy and influential patrons. If a patron had a project in mind and did not yet have an artist to execute it, he might consult trusted advisers for recommendations, thus making networking essential for artists seeking employment. Associations with key humanists also allowed Filarete greater access to ancient sources than he would have been able to achieve on his own. For one thing, these relationships would have enabled him to seek assistance with ancient languages, particularly for Latin inscriptions included in his commissions. ${ }^{52}$ They also afforded him exposure to the trends of philosophical thought circulating amongst his contemporaries. It is difficult to imagine how an architect with little formal education would otherwise be able to draw on the types of ancient authorities -Plato, Cicero and Macrobius, for instance- that Spencer and others have identified as likely sources for certain ideas in the Libro. ${ }^{53}$ As advisers to ruling patrons, court humanists not only were aware of contemporary intellectual and cultural trends, but played a hand in shaping courtly tastes. Filarete's associations with key scholars therefore likely enlightened him about the intellectual interests of his current and potential patrons.

\section{Filarete's appeal}

As already discussed, Filarete's Libro attracted the attention of patrons beyond his immediate network and was copied for their collections. The decision to commission a high-quality manuscript copy of any text was not one that a patron would have made lightly; to have an expert scribe and an illuminator produce a duplicate version would have taken considerable time, effort and expense. This is particularly true of the manuscript copy that Corvinus commissioned, as it is not only the most elaborately illuminated version of Filarete's Libro, but it also had attendant translation costs. (Illustration 8)

Why would these patrons go to such lengths to obtain beautiful copies of an architectural treatise which some scholars have been quick to characterise as theoretically lightweight and of little practical application? One explanation is to argue that in amassing library collections to broadcast one's erudition, quantity was a more immediate concern than quality. ${ }^{54}$ The more likely scenario, however, is that

\footnotetext{
52. It is likely that Filarete's grasp of Latin was scanty at best, and that he had no working knowledge of Greek. Onians, John. Bearers of Meaning...: 158-160.

53. Filarete. Treatise on Architecture...: 265, No. 10; Onians, John. “Alberti and ФІААРЕТН...": 105-106; Onians, John. Bearers of Meaning...: 159-160; Giordano, Luisa. "Filarete's Libro Architettonico...": 57; Lang, Susanne. "Sforzinda, Filarete and Filelfo...": 391-392; Hub, Berthold. "Filarete and the East: The Renaissance of a Prisca Architectura". Journal of the Society of Architectural Historians, 70/1 (2011): 19.

54. On the collections of Federico da Montefeltro (1422-1482) and Cosimo de' Medici (1389-1464), for example, see Bisticci, Vespasiano da. Vite di uomini illustri del secolo XV. Florence: Rinascimento del Libro, 1938: 101-109, 273-274.
} 
the treatise appealed to patrons on key intellectual and cultural levels, beyond those usually considered in studies of Filarete and his Libro. It is therefore productive to explore some of the broader intellectual themes that emerge in Filarete's Libro that would have made the text particularly appealing to patrons. This necessarily begins with Filarete's treatment of the ideal city, and the conventional cultural references associated with ideal design. Next, Filarete's consistent attention to cosmology and astrology in his conception of architecture is examined, paying particular attention to the overt mentions of Claudius Ptolemy (c. 100-c. $170 \mathrm{AD}$ ) that have otherwise gone unremarked. Finally, the recurrent references to Alexander the Great are assessed as a metaphor of universal empire. The inclusion of these themes was not simply an unconscious adoption of common cultural references, but rather a deliberate effort by Filarete to channel the intellectual trends that were important to the ruling elite and to make them inseparable from his architectural theories. In so doing, he established his relevance as an architect who both was aware of the concerns most relevant to patrons, and asserted his capacity to help them achieve their political ambitions through architecture and urban design.

\subsection{The ideal city}

The crux of Filarete's treatise, and the source of much of its innovation, is the proposed design and foundation of the fictional ideal city, Sforzinda. Drawing from the ancient precedent of symmetry and proportion signifying perfection in design and emulation of the natural order of the cosmos, Filarete proposes a radial city, inscribed in a circle, with an outer wall shaped like a symmetrical, eight-pointed star. $^{55}$ (Illustration 9) In keeping with the centrally-planned form traditionally associated with ideal environments, the church, centres of government and markets -all places of public congregation and civic significance- are clustered at the heart of the city and align to a grid. This centre is both the conceptual and geometric focal point, from which eight avenues, alternating with eight canals, spread out in an equidistant arrangement to the city's perimeter. The outer wall has a rhythmic pattern as well: a defensive tower tops each protruding angle, while each inset angle houses a gate.

Not simply pursuing idealism in aesthetics, however, Filarete focuses on the city's functionality and the wellbeing of its inhabitants. The citizenry of Sforzinda is integral to fostering a harmonious society in Filarete's vision. Rather than envisioning the city as springing, fully formed, from the architect's imagination, Filarete describes how the citizens would participate in its ongoing construction and growth, proposing a city flexible enough to develop according to the demands of its citizens and its patron. This implies that a harmonious society is self-generating

55. Lang, Susanne. "Sforzinda, Filarete and Filelfo...": 392; Hart, Vaughan. "Paper Palaces...": 23; Eaton, Ruth. Ideal Cities: Utopianism and the (Un)Built Environment. London: Thames \& Hudson Ltd., 2002: 47-48; Powers, Jonathan. "Building Utopia: The Status of the Ideal in Filarete's Trattato", Imagining and Making the World: Reconsidering Architecture and Utopia, Nathaniel Coleman, ed.. Bern: Peter Lang AG, 201 1: 29-56. 
if given the ideal form upon which to build, a model for understanding urban development which parallels natural life cycles and thus underscores the ultimate perfection of Filarete's plans.

Ideal design allows Sforzinda to function smoothly and efficiently, both in terms of its population and its infrastructure. Of preeminent concern is civic health, and Filarete follows Vitruvius in emphasizing sanitation. He frequently refers to the need for cleanliness in the city, and devotes significant attention to the incorporation of running water into the designs both of the public civic spaces and of individual buildings. ${ }^{56}$ The layout of the city itself expresses this preoccupation: architect and patron collaborate to come up with the alternating radial street/canal layout, and the canals are designed both to bring fresh water into the city, as well as to clean the walkways and common areas, thus keeping them orderly. ${ }^{57}$ Sanitation concerns are foregrounded in discussions of the city's hospital. Filarete proposes a complex system of reservoirs and canals that remove waste from the building, and he is careful to make provisions so that no cattivo odore ("bad odour") can permeate the sick wards and affect patients. ${ }^{58}$

Despite the Libro's overwhelming emphasis on the perfection of geometric forms, when Filarete discusses the design of the city it becomes clear just how much aesthetics blend seamlessly with practicality. While the radial waterways serve to bring fresh water into and expel waste from the city, they alternate with the main streets, which mirror their function by providing equidistant, easily accessible avenues into and within Sforzinda, allowing for the pedestrian circulation of its inhabitants. ${ }^{59}$ The accessibility and navigation of the urban space are inherently linked to its perfect geometric design. Similarly, the idealised design of the city enables its defence. Each gated entrance to the city, set within a joint of the starshaped outer wall, is protected by the towers in each of the wall's protruding angles that flank the gate on either side.$^{60}$ The encircling moat also affords a regular barrier, allowing adequate time, from any of the eight defensive towers, to retaliate against attackers. That the city's design is so linked with its various functions underscores the harmony of that design.

Filarete also devotes considerable attention to the effects of urban design on the city's social hierarchy. The Platonic notion of social order and urban fabric as conducive to fostering a just society plays out in Filarete's Sforzinda, where the social ramifications of architecture are central to his conception of the city. When laying Sforzinda's foundations, Filarete likens its inhabitants to bees, noting that they are solleciti e severi e giusti, e vogliono e hanno signore e principale tra loro, e seguitano

56. See Filarete. Trattato di Architettura...: I, 105, 237, 299-305.

57. Filarete. Trattato di Architettura...: I, 167.

58. Filarete. Trattato di Architettura...: I, 299-305.

59. Filarete. Trattato di Architettura...: I, 167-168.

60. Filarete. Trattato di Architettura...: I, 112-114. 
tutte il comandamento del loro principale, e tutti sono diputati quello che hanno a fare, e ognuno ubbidisce. ${ }^{61}$

Building on Alberti's clarification of the Vitruvian architectural orders, Filarete associates the orders with a clear social hierarchy, embedded in Sforzinda's layout. Not only do the aesthetics of buildings correspond to their inhabitants' social standing, but the city is composed according to distinctions of function and class -in addition to the structures required by the city's lords and men of religious orders, Filarete identifies the need for private palazzi da gentili uomini, e casamenti da populari e da comuni artigiani e da persone di bassa condizione e poveraglia. ${ }^{62}$ The Libro devotes significant attention to the central piazzas of the city, allocating one to the merchants, one to the market and one for general congregation. ${ }^{63}$ Beyond placing the nobility's residences around the city centre where all essential civic functions occur, Filarete devotes very little attention to the periphery of the city - presumably where members of the lower classes would reside. ${ }^{64}$ In Filarete's words, the poor non $v^{\prime}$ entra troppa spesa, neanche magistero; degli altri solamente delle case di fuori alle ville, $e$ anche di queste si farà menzione. ${ }^{65}$

This social bias makes sense when we recall that this is a work written first and foremost for a wealthy tyrant looking to assert his right to sovereignty over Milan. Princes were understood to demonstrate their nobility of character and magnificentia through displaying wealth in the form of public commissions. ${ }^{66}$ By marrying the principles of the urban design, which channelled the harmonies of the world and echoed the divine order, with theories of social order, Filarete made his Libro and the architectural principles contained therein of immediate relevance to ruling patrons. An ordered urban space served as a metaphor for good government, and it is no coincidence that this notion of the ideal city emerged not long after the development of linear perspective, and at a time when representations of clean, ordered, geometrical urban spaces were popular among patrons. ${ }^{67}$

61. "industrious, severe, and just. They desire and have a lord and ruler over themselves and they follow all his commands. Everyone has a task and everyone obeys". Filarete. Treatise on Architecture...: 45. Filarete. Averlino, Antonio (Filarete). Trattato di Architettura...: I, 105. The simile recurs on Averlino, Antonio (Filarete). Trattato di Architettura...: I, 175.

62. "palaces of gentlemen and the houses of the people, of common artisans, of persons of low condition, and the poor". Filarete. Treatise on Architecture...: 21. Averlino, Antonio (Filarete). Trattato di Architettura...: I, 51-52. Onians, John. Bearers of Meaning...: 165-170; Giordano, Luisa. "Filarete's Libro Architettonico...": 58-62. On the parallel here to Alberti, see Lang, Susanne. "Sforzinda, Filarete and Filelfo...": 397.

63. Filarete. Trattato di Architettura...: I, 165-168, 235-237.

64. Filarete. Trattato di Architettura...: II, 607-608.

65. "require little expense or art. Only the [other classes] and houses outside the city will be mentioned". Filarete. Treatise on Architecture...: 21. Averlino, Antonio (Filarete). Trattato di Architettura...: I, 52.

66. See Fraser Jenkins, Anthony David. “Cosimo de' Medici's Patronage of Architecture and the Theory of Magnificence". Journal of the Warburg and Courtauld Institutes, 33 (1970): 162; Welch, Evelyn S. Art and Authority in Renaissance Milan. New Haven-London: Yale University Press, 1995: 203; Kent, Francis William. Lorenzo de' Medici and the Art of Magnificence. Baltimore: The Johns Hopkins University Press, 2004: 46-47.

67. Krautheimer, Richard. "The Panels in Urbino, Baltimore and Berlin Reconsidered", The Renaissance from Brunelleschi to Michelangelo: The Representation of Architecture, Henry A. Millon, Vittorio Magnago 


\subsection{Invoking the Heavens}

Another attempt at attracting the interest of patrons and legitimizing his treatise is Filarete's extensive inclusion of cosmological references throughout the Libro. Through his insistence on the importance of astrology and the narrative's repeated anecdotes involving auguries and omens, Filarete reminds us that his architectural designs align with the natural order and are divinely sanctioned..$^{68}$ For example, in enumerating the skills required to be a proficient architect, Filarete acknowledges that the architect must know astrology, since quando ordina e fa una cosa, che guardi a principiare su buono pianeto e su buona costellazione. ${ }^{69}$ Such issues were of genuine concern in the conduct of the Milanese nobility, both during Filarete's time in Francesco Sforza's service and continuing well after his departure. Astrological applications at the Sforza court were various, ranging from matters as general as ascribing personality traits to new-borns, to predicting specific political and military outcomes..$^{70}$ Such concerns extended to the pragmatics of daily life as well. In 1495 Isabella d'Este (1474-1539) recounted how she was delayed in her departure from Milan because Duke Ludovico Sforza (1452-1508) insisted she wait for auspicious astrological calculations before travelling. ${ }^{71}$

Filarete's designs themselves often include embedded cosmological suggestions, drawing on the notion that ideal architecture discerned and emulated the harmonic proportions of the cosmos's divine order. ${ }^{72}$ Sforzinda's radial layout, through its highly ordered and proportional geometry, reflects on a very basic level the longstanding conception of the circular structure of the cosmos, which radiates outward from the world in concentric rings..$^{73}$ The city's central tower has tante finestre per rispetto che come l'anno è tanti dì, with varied shapes and arrangements to evoke the four seasons, as well as acknowledging the existence of both night and day. ${ }^{74}$ (Illustration 10).

\footnotetext{
Lampugnani, eds. London: Thames \& Hudson Ltd., 1994: 255; Eaton, Ruth. Ideal Cities...: 50.

68. Hart, Vaughan. "Paper Palaces...": 28.

69. "when he orders and builds a thing, he should see that it is begun under a good planet and constellation". Filarete. Treatise on Architecture...: 198. Averlino, Antonio (Filarete). Trattato di Architettura...: II, 429. The Libro includes many other examples: see Averlino, Antonio (Filarete). Trattato di Architettura...: I, 14, $101-103$.
}

70. Azzolini, Monica. The Duke and the Stars: Astrology and Politics in Renaissance Milan. Cambridge (Mass.): Harvard University Press, 2013: 65-98; Bini, Daniele, ed. Astrologia: arte e cultura in età rinascimentale. Modena: Il Bulino edizioni d'arte, 1996: 32-38.

71. Shemek, Deanna, ed. Isabella d'Este: Selected Letters. Toronto-Tempe: Iter Press-The Arizona Center for Medieval and Renaissance Studies, 2017: 69.

72. Long, Pamela O. "Contribution of Architectural Writers...": 268; Eaton, Ruth. Ideal Cities...: 48.

73. Nuti, Lucia. Cartographie senza carte: Lo spazio urbano descritto dal Medioevo al Rinascimento. Milan: Editoriale Jaca Book SpA, 2008: 114-116; Johnston, Norman J. Cities in the Round. Seattle: University of Washington Press, 1983: 3-30.

74. “as many windows as the year has days". Filarete. Treatise on Architecture...: 72. Averlino, Antonio (Filarete). Trattato di Architettura ...: I, 162. 
Both of these examples demonstrate Filarete's interest in suggesting his architecture's relevance to the world as a whole, a theme upheld by the text's frequent emphasis on the harmonious relationship of Sforzinda with its natural settings. ${ }^{75}$ (Illustration 11) Filarete enumerates the plentiful resources in the city's environs, describing at length how they contribute to the city's construction and the site's hospitability, as though nature itself encourages the city's development and the architecture emerges effortlessly from the earth. ${ }^{76}$ Filarete makes specific architectural references to the cosmos as well. The cathedral of Sforzinda includes a mosaic decorative program that spatially mimics the hierarchy of heaven and earth, and includes references to geography, the zodiac, the seasons and the elements. ${ }^{77}$ The interior of the church adjacent to Sforzinda's hospital similarly has a decorative program involving the cosmos, this time with tutti gli pianeti e le stelle fisse, in modo che chi entrava era amirazione e piaceva assai a chi le 'ntendeva. ${ }^{78}$ Finally, Filarete describes the garden of the temple in Plusiapolis, which mirrors a map of the earth, and whose streams flowing in and out of the centre of the circle recall the layout that Filarete chose for Sforzinda itself. ${ }^{79}$ (Illustration 12) There is also an easily recognizable Biblical parallel to the four rivers of paradise stemming from the garden of Eden. This ties in seamlessly with Filarete's assertion that Adam, upon his expulsion from Eden and needing to create shelter, was the first architect. ${ }^{80}$

These explicit cosmological references make the link between architecture and the cosmos in Filarete's ideal urban program difficult to overlook, and are reinforced by the three instances in which Ptolemy appears in the text. ${ }^{81}$ In the first, Ptolemy is offered as an example of the strologi e matematici $i$ quali hanno trovate queste scienze di misurare $i$ cieli e anche la terra in a description of the painted decorations of the court. ${ }^{82}$ The second occurs during a description of the fresco program of the House of Virtue and Vice, and situates Ptolemy among quegli primi che misurorono il cielo e quegli che misurorono la terra ancora, referring to Tolomeo d'Egitto ("Ptolemy of Egypt"),

75. On the long tradition of likening the world to a city: Lang, Susanne. "Sforzinda, Filarete and Filelfo...": 392-395.

76. Filarete. Trattato di Architettura ...: I, 53-60, 65-88. Whittemore, Leila. "City and Territory...": 48.

77. Filarete. Trattato di Architettura...: I, 247-249. Lang, Susanne. "Sforzinda, Filarete and Filelfo...": 392.

78. "all the planets and fixed stars [...] to the great admiration of anyone who entered and to the great pleasure of anyone who understood it". Filarete. Treatise on Architecture...: 144. Filarete. Trattato di Architettura...: I, 317.

79. Filarete. Trattato di Architettura...: II, 451. Lang, Susanne. "Sforzinda, Filarete and Filelfo...": 393.

80. Filarete. Trattato di Architettura...: I, 18, 23-25; Rykwert, Joseph. The Dancing Column: Or Order in Architecture. Cambridge (Mass.): Masachussetts Institute of Technology Press, 1996: 65.

81. Today Ptolemy would be considered an astronomer, but the astrology/astronomy distinction was not so pronounced in the fifteenth century. That Ptolemy based his mapping of the earth on charting the heavens further blurs the line between disciplines. Edgerton, Jr., Samuel Y. “Florentine Interest in Ptolemaic Cartography as Background for Renaissance Painting, Architecture, and the Discovery of America". Journal of the Society of Architectural Historians, $33 / 4$ (1974): 279.

82. "astrologers and mathematicians who discovered the science of measuring the skies and the earth". Filarete. Treatise on Architecture...: 1 16. Filarete. Trattato di Architettura...: I, 258. 
alongside Atlas, as one who misura il mondo. ${ }^{83}$ Filarete then goes on to describe how the fresco demonstrates ancient methods for charting the movements of the sun, stars (planets) and moon, discovering the twelve astrological signs, and using measurements of the heavens to construct divisions of time. ${ }^{84}$ Ptolemy emerges again in the final pages of the Codex Magliabechianus, in the section amended when Filarete rededicated the treatise to Piero de' Medici, as part of the proposed decorative program in the Banco Mediceo in Milan: mi pareva doverci dipignere nella volta del detto andito della porta le stelle fisse, e nelle facciate da canto si può fare la cosmografia, e così da parte Tolommeo e altri strologi. ${ }^{85}$

Considering the attention devoted to cosmology in the Libro, the references to Ptolemy are not altogether surprising: specifically referring to Ptolemy lends recognizable authority to Filarete's architectural theories and underscores how he aligned them with cosmological order. His inclusion of Ptolemy —particularly his addition of a third reference in his amended version of the treatise- also suggests a knowing assertion of its cultural relevance, given the intellectual climate in which it was written. In the mid-fifteenth century, Ptolemy was the preeminent ancient authority on astrology and cosmology; once the Geographia became accessible in Italy, that reputation extended to geography as well. ${ }^{86}$ His work was of specific interest in many of the courts at the time. The Geographia quickly became a popular text for nobles to possess, and beautifully illuminated manuscripts made their way to courts throughout Europe. ${ }^{87}$ Federico da Montefeltro (1422-1482) even commissioned a portrait of Ptolemy for the studiolo in the Ducal Palace of Urbino (now in the Musée du Louvre), as part of a cycle of 28 panel paintings depicting famous thinkers.

Though not an astronomer or cartographer, Filarete was undeniably influenced by general interest in the ancient authority. He trained in Florence, where Ptolemy's Geographia first reached Italy roughly sixty years before he wrote his Libro, and where knowledge of Ptolemy was both intellectually and politically in vogue. His mentor, Filelfo, had studied Greek in Venice with Manuel Chrysoloras (c. 13501415), the scholar who brought Ptolemy's Geographia to Italy and translated it into Latin. ${ }^{88}$ Filarete worked during a time when perspective and mapmaking techniques were transforming how people perceived and were able to represent the world

83. "those who first measured the sky and the earth"; "measurer of the world". Filarete. Treatise on Architecture...: 264. Averlino, Antonio (Filarete). Trattato di Architettura ...: II, 574.

84. Averlino, Antonio (Filarete). Trattato di Architettura...: II, 575.

85. "I thought they ought to paint the fixed stars in the vault of the passage of the door, and on the side façade they could make a cosmography with Ptolemy and the other astrologers inside it". Filarete. Treatise on Architecture...: 329. Averlino, Antonio (Filarete). Trattato di Architettura...: II, 704.

86. Blair, Ann; Grafton, Anthony. "Reassessing Humanism and Science". Journal of the History of Ideas, 53/4 (1992): 537; Grafton, Anthony. "Ptolemy", The Classical Tradition, Anthony Grafton, Glenn W. Most, Salvatore Settis, eds. Cambridge (Mass.): The Belknap Press of Harvard University Press, 2010: 791.

87. Miller, Naomi. "Mapping the City: Ptolemy's Geography in the Renaissance", Envisioning the City: Six Studies in Urban Cartography, David Buisseret, ed. Chicago: The University of Chicago Press, $1998: 34$.

88. Roberts, Sean. Printing a Mediterranean World: Florence, Constantinople, and the Renaissance of Geography. Cambridge (Mass.): Harvard University Press, 2013: 22-23. 
as a unified whole. ${ }^{89}$ For Filarete's patrons and humanist friends, geography, as well as astrology and cosmology, would have been essential knowledge and were undoubtedly a part, even if only superficially, of their interactions with him. ${ }^{90}$

The significance of astronomical and astrological knowledge is evident from the kinds of books patrons commissioned and collected in their libraries. Francesco Sforza's library had a section devoted exclusively to astrology. ${ }^{91}$ The Medici library holdings also list several astrological manuscripts and astrological themes were represented in artistic commissions, such as the dome fresco of constellations in the Old Sacristy of San Lorenzo. Given the intellectual ambitions of his patrons, it is thus no surprise that Filarete gives the discipline of astrology primacy of place on the very top floor, messa di sopra da tutte, of the House of Virtue, Sforzinda's universally accessible centre for education. ${ }^{92}$

\subsection{Metaphors of universal sovereignty}

Another recurring figure in the Libro architettonico is Alexander the Great. Though Alexander would have been best known for his far-reaching conquests and establishment of an empire that covered much of the known world, Filarete uses him in the treatise as a model for the ideal patron, paired with his architect, Dinocrates. Filarete relates the story — narrated by Vitruvius and derived from Petrarch (13041374)'s Life of Alexander - of how, after capturing his patron's attention, Dinocrates enters into a respectful and fulfilling professional arrangement with Alexander. ${ }^{93}$ The parallel to Filarete's own situation is difficult to overlook, particularly given how much of the treatise he devotes to illustrating an ideal patronage relationship. Filarete's analogy between the ancient artist and himself is cemented when he justifies his designs for Sforzinda's towers by referencing the similarity of their decorations to those devised for the structures that Alexander had Dinocrates erect on Mount Caspi:

a ogni torre una figura di bronzo, a similitudine di quel vento, con una bandiera in mano, che la tenghino ben ferma, acciò che se spira quel vento, la faccia voltare in modo sia

\footnotetext{
89. Edgerton, Jr., Samuel Y. “Florentine Interest...": 287; Onians, John. Bearers of Meaning...: 158.

90. Cosgrove, Denis. "Globalism and Tolerance in Early Modern Geography". Annals of the Association of American Geographers, 93/4 (2003): 860; Grafton, Anthony. "Girolamo Cardono and the Tradition of Classical Astrology: the Rothschild Lecture, 1995". Proceedings of the American Philosophical Society, 142/3 (1998): 338; Miller, Naomi. “Mapping the City...": 44-45.

91. Bini, Daniele. Astrologia: arte e cultura...: 34.

92. "placed above all others". Filarete. Treatise on Architecture...: 249. Filarete. Trattato di Architettura...: II, 540.

93. Filarete. Trattato di Architettura...: I, 45-46. Johnston, Marina della Putta. "Literary Cornice of Architecture...": 14-15.
} 
congegnata e, se possibile fusse, che tenessino una tromba in mano, e quando vento traesse sonassono, come dice che facevano quelle che fe' fare Alessandro a Monte Caspi ${ }^{94}$

Not only is Alexander a part of the narrative that Filarete advances; he also features in the decorative program of the hall inside the ducal court building in Sforzinda, continuing the roster of famous Biblical and historical individuals painted outside. ${ }^{95}$

Alexander had been a figure of fascination since antiquity, largely driven by such influential portrayals as Plutarch's biography of the Macedonian king, Arrian's Anabasis Alexandri and the exceedingly popular anonymous Alexander Romance. ${ }^{96}$ The appeal of the Alexander legend persisted throughout the early modern period and, upheld as both a military and moral example, Alexander remained a model to whom rulers could compare themselves. Fabio Chigi (Pope Alexander VII) (15991667), for instance, underscored the magnificence of his urban planning program for Rome by inserting himself into the story about Alexander the Great establishing the prosperous Alexandria. ${ }^{97}$ In addition to commissioning such images for themselves, patrons also exchanged Alexander-themed gifts, intended to flatter the recipient with the analogy. ${ }^{98}$ The marble reliefs of Alexander and Darius —now in the collection of The National Gallery of Art in Washington, DC - that Lorenzo de' Medici sent to Matthias Corvinus in 1480, implied an analogy between Corvinus/ Alexander facing the modern Darius: the Ottoman threat. ${ }^{99}$

94. "a bronze figure on each tower representing each wind. It will hold a banner firmly in its hand so that when the wind blows it will turn. It will be designed in such a way, if possible, to hold a trumpet in its hand and when the wind blows the trumpet will sound, as they say those that Alexander had made on Mount Caspi did". Filarete. Treatise on Architecture ...: 60. Filarete. Trattato di Architettura...: I, 136. Günther, Hubertus. "Society in Filarete's Libro architettonico between Realism, Ideal, Science Fiction and Utopia". Arte Lombarda, 155 (2009): 56.

95. Averlino, Antonio (Filarete). Trattato di Architettura...: I, 262-263.

96. Centanni, Monica. "Alexander the Great", The Classical Tradition, Anthony Grafton, Glenn W. Most, Salvatore Settis, eds. Cambridge (Mass.): The Belknap Press of Harvard University Press, 2010: 2830; Hannestad, Niels. "Imitatio Alexandri in Roman Art", Alexander the Great: Reality and Myth, Jesper Carlsen ed. Rome: L'Erma di Bretschneider, 1993: 61-68; Montgomery, Hugo. "The Greek Historians of Alexander as Literature", Alexander the Great: Reality and Myth, Jesper Carlsen ed. Rome: L'Erma di Bretschneider, 1993 93-98.

97. Habel, Dorothy Metzger. The Urban Development of Rome in the Age of Alexander VII. Cambridge: Cambridge University Press, 2002: 301-311. See Pietro da Cortona (1596-1669)'s drawing of Pope Alexander VII and Mount Athos, housed in the prints and drawings collection of The British Museum. 1860,0616.27.

98. Pócs, Dániel. "The history of the campaigns of Alexander the Great from the library of Matthias Corvinus", Matthias Corvinus, the King: Tradition and Renewal in the Hungarian Royal Court, 1458-1490, Péter Farbaky, ed. Budapest: Budapest History Museum, 2008: 235.

99. Békés, Enikö. "Matthias Corvinus' Iconography", Matthias Corvinus, the King: Tradition and Renewal in the Hungarian Royal Court, 1458-1490, Péter Farbaky, ed. Budapest: Budapest History Museum, 2008: 215-216; Nagy, Balázs. "The Political Face of Central Europe in the Time of Matthias Corvinus", Matthias Corvinus, the King: Tradition and Renewal in the Hungarian Royal Court, 1458-1490, Péter Farbaky, ed. Budapest: Budapest History Museum, 2008: 205-208. 
Alexander's appeal was not simply due to his success as a political and military leader, but was also associated with the far-reaching expansion of his empire. Alongside Julius Caesar, Alexander was a figurehead for the ideal of universal empire. As exploration and cartography became increasingly important to rulers, Alexander's association with geography solidified. Medieval and early modern maps frequently included scenes from the Alexander Romance, alongside references to the Roman Empire and Biblical stories. ${ }^{100}$

When paired with the Libro's Alexandrine allusions, Filarete's cosmological and Ptolemaic references assume greater significance. His treatise not only provides a plan for a city that acts as a microcosm and a distillation of divine order, but it also offers its patrons the model of a historical figure who had been understood as an example of governance for centuries. Linking the concepts of the ideal, microcosmic city with notions of geography and cosmology, and then ultimately presenting Alexander as a key model for patrons, the Libro presents an idealistic glimpse at how architecture might aid the achievement of universal sovereignty.

\section{Conclusion}

A close reading with a sensitivity to its cultural context suggests that the Libro was a savvy appeal to its intended audience. The complex references and themes embedded within the text and its accompanying illustrations were not included by chance or coincidence. For an artist to draw upon cultural themes that he knew would speak to patrons' specific sensibilities and interests is noteworthy. That Filarete, a relatively uneducated artist compared to his patrons and many of his colleagues, made the most of the resources he had to hand is particularly impressive.

At the centre of this ambitious undertaking, of course, is Filarete himself. He is inextricably embedded in the Libro both in numerous verbal and visual allusions and as its protagonist narrator. Much like Alberti's treatises, the Libro synthesises Filarete's artistic identity, presenting his ideas about architecture -without the constraints of actual construction - in a way that other works could not. The Libro could deftly characterise the artist as a theoretician for the benefit of current and potential patrons while illustrating the personal and intellectual qualities that made him a plausible candidate for a prestigious courtly role. Promoting himself in this way ensured Filarete a permanent place in the courts of important patrons, if not in their direct employ, then at least in their libraries.

100. Barber, Peter, Harper, Tom. Magnificent Maps: Power, Propaganda and Art. London: The British Library, 2010: 78 . 
Measuring and Making the World: Self-Promotion, Cosmology and Elite Appeal 407

\section{Illustrations}

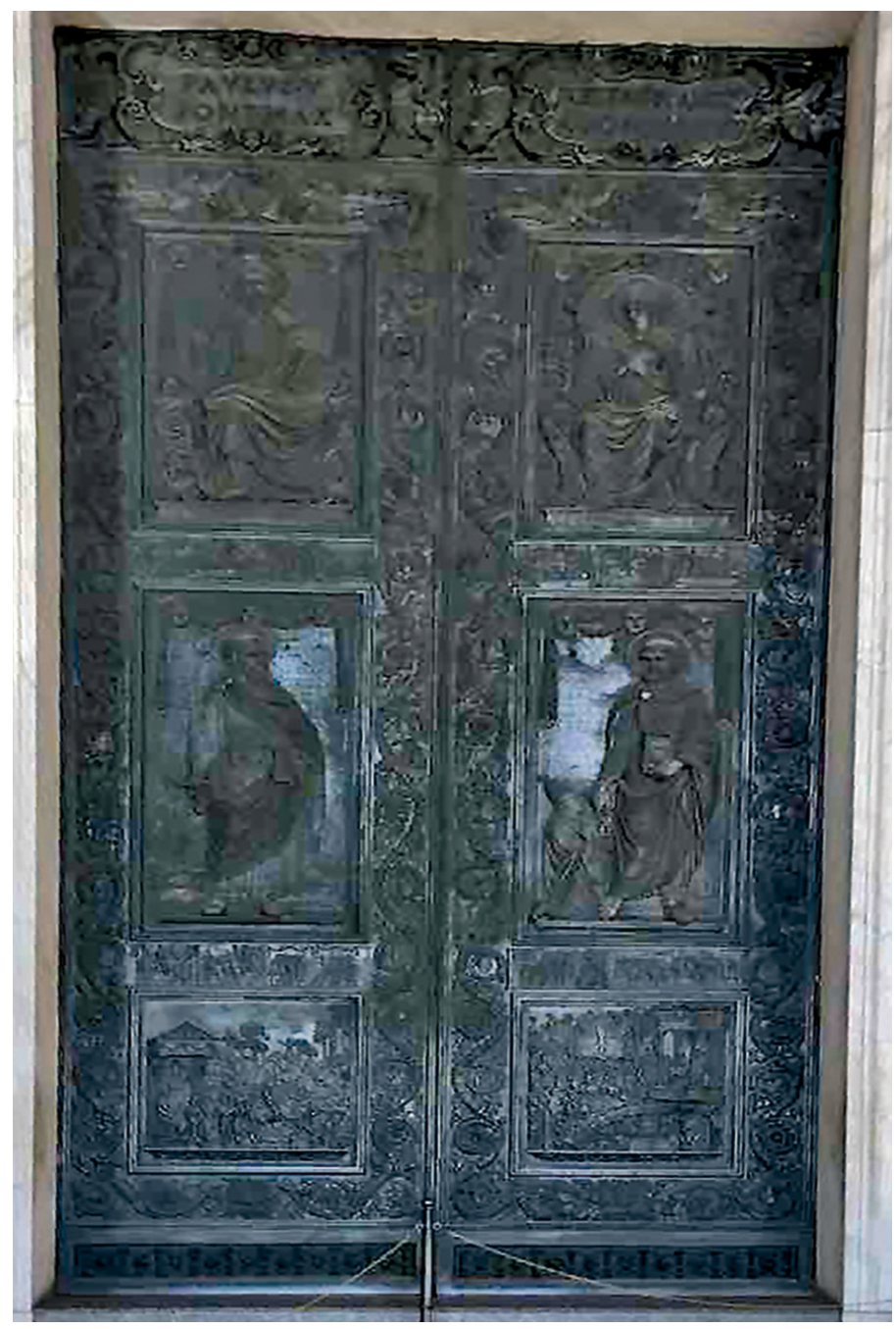

Illustration 1. Filarete. Doors of St. Peter's. Rome (1433-1445). Bronze. Basilica Papale di San Pietro in Vaticano. Рhotograph by THE AUTHOR. 


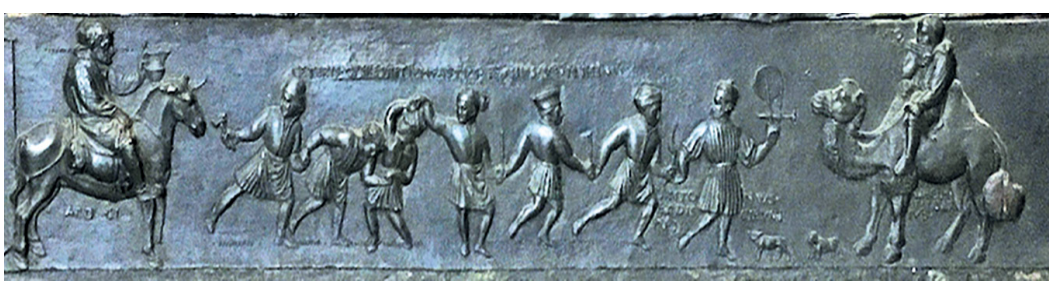

Illustration 2. Filarete. Self-Portrait with Assistants (reVerse of left door of the Doors of St. Peter's). Bronze. Rome (1433-1445). Basilica Papale di San Pietro in Vaticano. Photograph by the author.

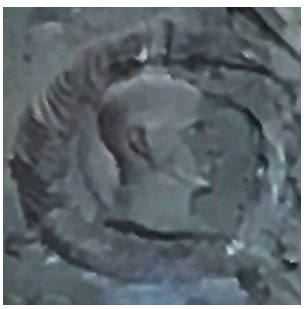

Illustration 3. Filarete. Self-portrait ROUNDEL (DETAIL ON THE LEFT DOOR OF THE Doors of St. Peter's). Rome (14331445). Bronze. Basilica Papale di San Pietro in Vaticano. Photograph by the AUTHOR.

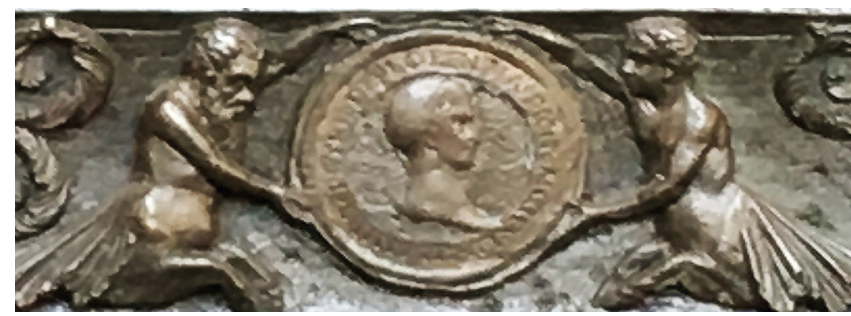

Illustration 4. Filarete. Self-portrait medallion (Detail on the Left door of the Doors of St. Peter's). Bronze. Rome (1433-1445). Basilica Papale di San Pietro in Vaticano. Photograph by the author.

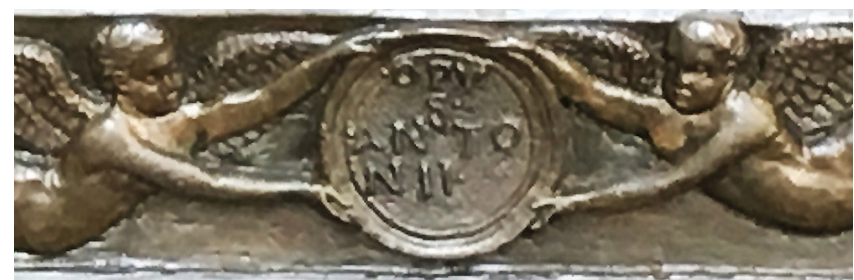

Illustration 5. Filarete. Signature inscription (Detail on the Right door of the Doors of St. Peter's). Bronze. Rome (1433-1445). Basilica Papale di San Pietro in Vaticano. Photograph by the author. 

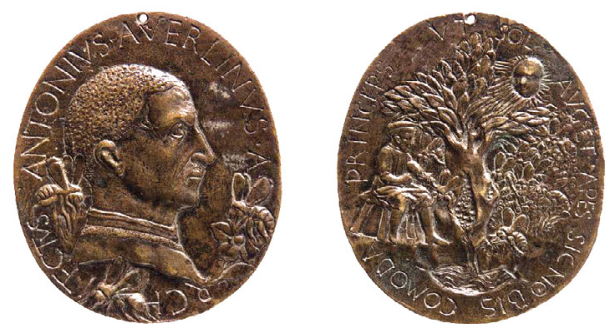

Illustration 6. Filarete. Self-Portrait Medal, Reverse: Filarete's device. Milan (c. 14641465). Bronze. Castello Sforzesco, Milan. Image from Web Gallery of Art.

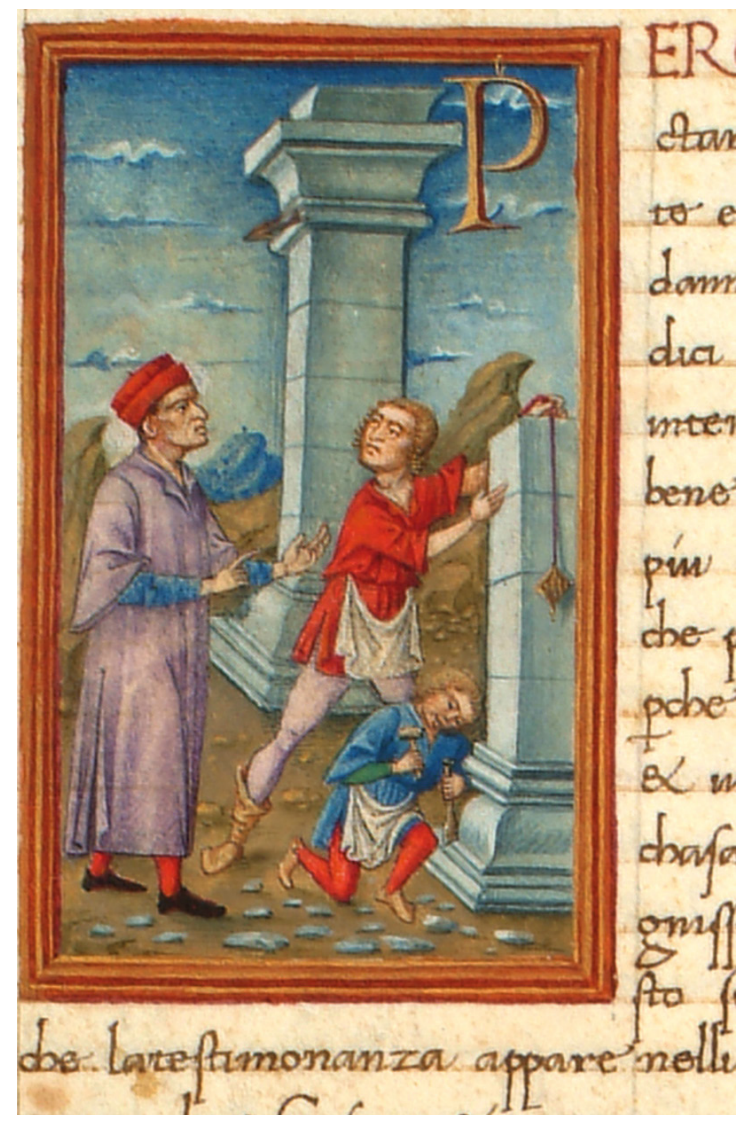

Illustration 7. Filarete. Illuminated initial $P$ With PATRON CONVERSING WITH ARCHITECT AND MASON. Milan (C. 1460-1464). Manuscript miniature. Biblioteca Nazionale Centrale di Firenze, Ms.Magl.II.I.140, f. 1 R. 

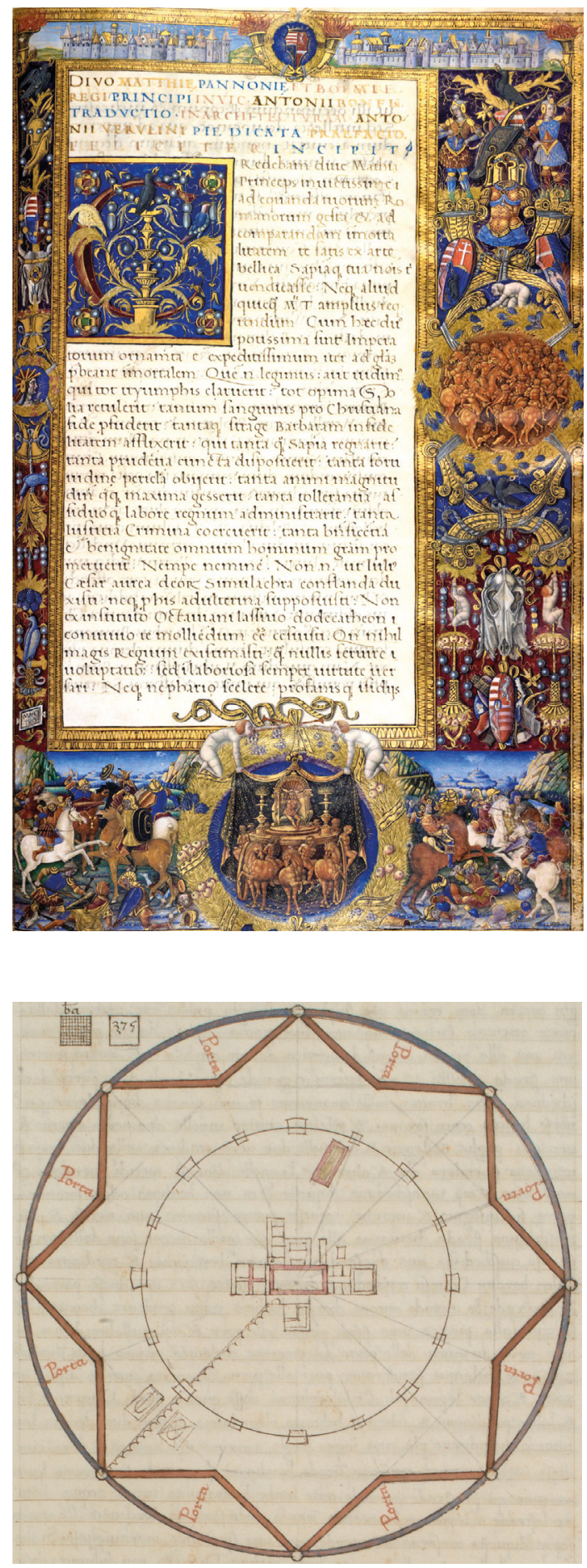

Illustration 8. After Filarete. Title page of the Codex Corvina. Buda (c. 14871489). Manuscript miniature. Biblioteca Nazionale Marciana, Venice, Ms.Lat. VIII.2, F.lR.

Illustration 9. Filarete. Plan for Sforzinda. Milan (c. 1460-1464). ManUscript miniature. Biblioteca Nazionale Centrale di Firenze, Ms.Magl.II.I.140, F. 43R. 


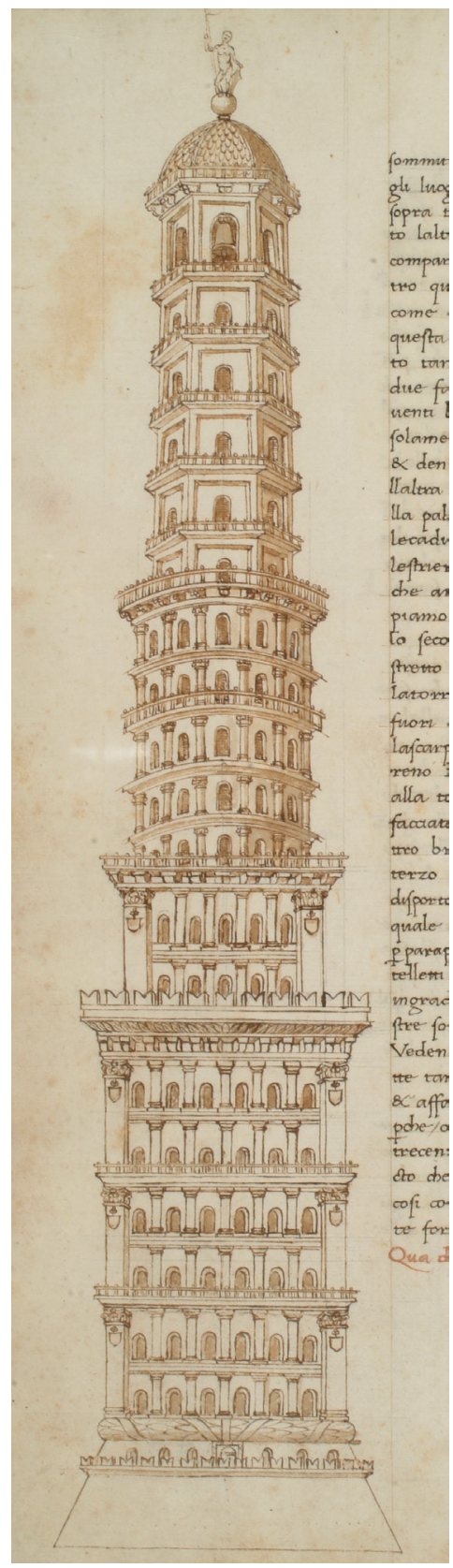

Illustration 10. Filarete. Central TOWER OF SFORZINDA. Milan (C. 14601464). MANUSCRIPT MINIATURE. Biblioteca Nazionale Centrale di Firenze, Ms.Magl.II.I.140, F. 41 v. 


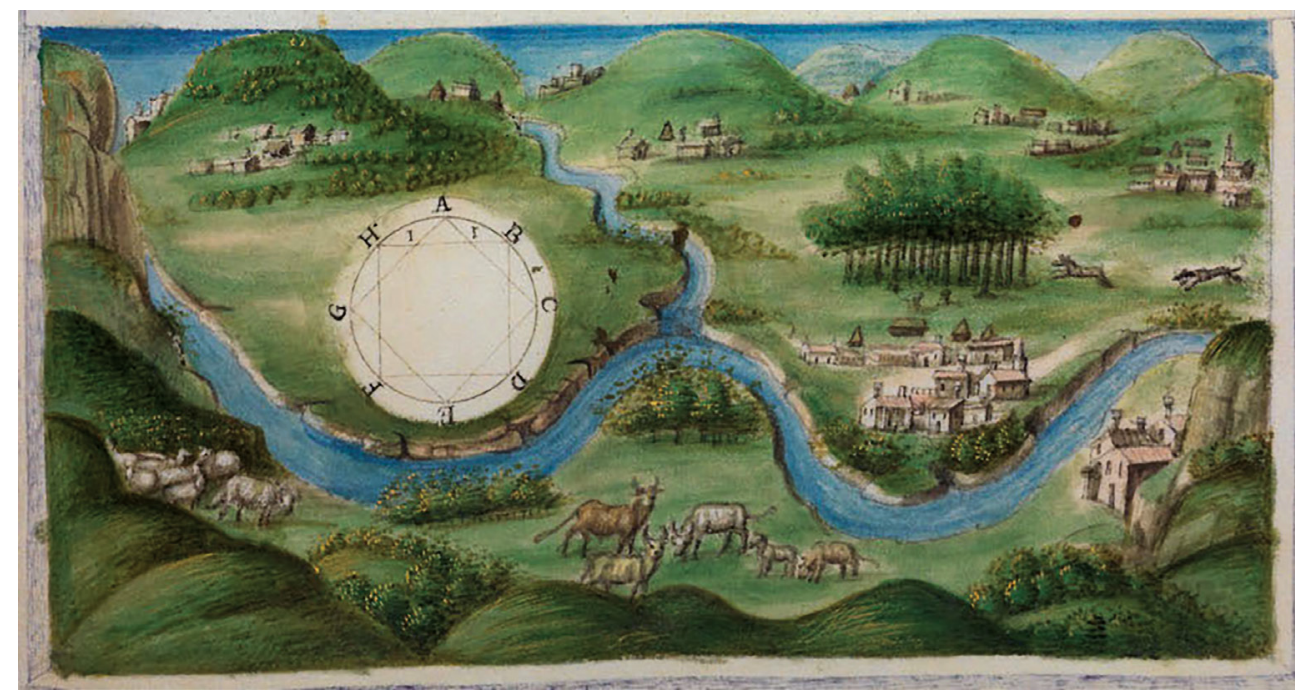

Illustration 11 . After Filarete. Sforzinda in landscape. Buda (c. 1487-1489). Manuscript miniature. Biblioteca Nazionale Marciana, Venice, Ms.Lat.VIII.2, f. l6r.

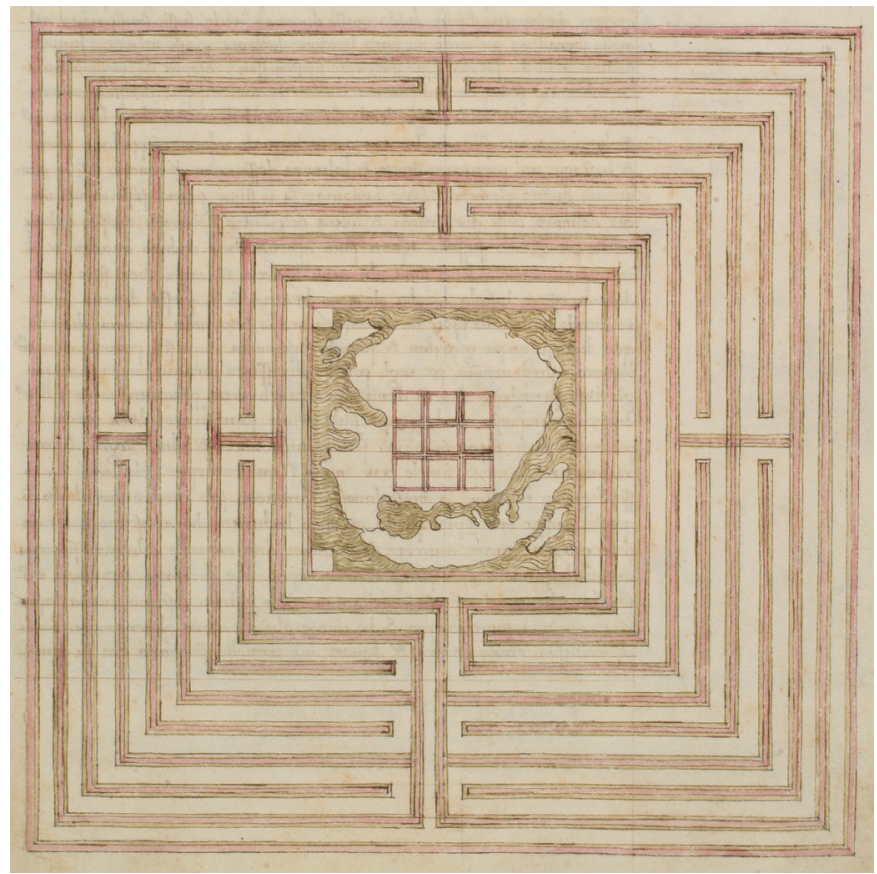

Illustration 12. Filarete. Garden Designed as a mappamondo. Milan (c. 1460-1464). Manuscript miniature. Biblioteca Nazionale Centrale di Firenze, Ms.Magl.II.I.140, F. 121 r. 